\title{
The Indian Dimension of Aceh and Sumatra History
}

\author{
Anthony Reid \\ College of Asia \& the Pacific, Australian National University, \\ Canberra, Australia
}

DOI: https://doi.org/10.14710/jmsni.v4i2.8639

\begin{abstract}
Indonesia's maritime boundary with India, lying barely $100 \mathrm{~km}$ from Banda Aceh, appears quiet and of little interest to policy-makers, in contrast to almost all the other contested boundaries with Malaysia, China, the Philippines, and Australia. India's historical relations with Sumatra have also drawn less scholarly or popular attention than those with the Arab, Persian, and Turkish worlds, or with Java, the Peninsula, and China. It is one of the imbalances and justifying the "Indian Ocean' in the title of International Centre for Aceh and Indian Ocean Studies. It is also supported by arguing that northern Sumatra's most important historical relationship outside Sumatra itself was for long with India. The time must come when this neighbourly maritime relationship is normalised in the context of improving Indonesia-India ties.
\end{abstract}

Received:

August 9, 2020

Revised:

December 24, 2020

Accepted:

December 24, 2020

*Corresponding Author: anthony.reid@anu.edu.au

Keywords: Indian Dimension; Historical Relationship; Indonesia-India Ties; Indian Ocean.

\section{Introduction}

Indonesia's (maritime) boundary with India is the least contested of its borders, perhaps just because it is the least often crossed. For many centuries before the twentieth it was normal for traders, adventurers and refugees to move from island to island, including the $150 \mathrm{~km}$ from Great Nicobar to Pulau We, in Aceh. But from the time the Dutch imposed naval blockades in the 1890s to block Aceh trade, up to the tacit agreement of both Indian and Indonesian independent governments to isolate India's Andaman and Nicobar Islands from their closest Southeast Asian neighbours, this ageold connection has been virtually dead.

This paper argues that it is time the neighbourly maritime relationship between Andaman/Nicobar and Aceh is normalised in the context of improving Indonesia-India ties more generally, especially those between South India and Sumatra. Indian and Indonesian scholarship have much to gain from each other, not only in exploring the intimate Buddhist, commercial and cultural interactions of the first common millennium, and the Muslim connections that followed, but also in understanding how these connections came to be severed in more recent times.

\section{Geology and Deep History}

The Nicobar and Andaman Islands form a geological continuum with Northwest Sumatra and its offshore islands, as the tectonic plate subduction that has caused such suffering to both. The 2004 earthquake and tsunami brought devastation to both regions, and proportionately to population most acutely in the Nicobar Islands. However, the response was radically different between the Indonesian section, thrown open to the world's aid organizations and researchers, and India's, which remained closed to foreign activity.

All the small islands that form the frontline of megathrust events, from Great Andaman to Mentawai, unlike small islands elsewhere in the Indonesian and Philippine Archipelagos, have shown a pattern of strong resistance to outside influences, even though their geographical location on the trade routes suggests ideal bases for passing merchants. Neither Indian religions nor Islam could get a foothold. The deep Sunda trench kept them separate from the mainland for at least 10,000 years, while the most northerly may always have been islands right through the last Ice Age. Their acute 
exposure to tsunamis must also explain some of this resistance, by periodically wiping out the coastal trading settlements of foreigners, and encouraging the surviving peoples to distrust the coast and the sea. In the 1890s it was reported that "All Andamanese tradition dates back to some great cataclysm which submerged a greater part of the land." (Portman 1899,18).

In different degrees these islands were therefore precious museums of older patterns of language, gene pools and cultural adaption. The Sumatran islands resisted Indian religions and Islam by these means, but could not resist the spread of Austronesian agricultural peoples several thousand years ago. The Nicobars were evidently colonised by Austro-Asiatic agriculturalists (broader Mon-Khmer), as were the Peninsula and Sumatra, long before the Austronesians. But the Australo-Melanesian (Papuan-like) hunter-gatherers of the Andamans fiercely resisted all the agricultural and commercial newcomers from the Austro Asiatic on through the earliest European traders and missionaries, until the British established a permanent presence and a penal colony there in 1859 (Portman 1899).

The Andamans therefore offered (when the indigenous element was intact in the nineteenth century) precious clues to the oldest population of island Southeast Asia and Australia, when the indigenous Austro-Melanesians spread as far as Papua and Australia. Andamanese languages were extremely various, and unrelated to present neighbours, but similarities have been traced to Papuan languages (Wurm).

The Nicobars, similarly, offer some clues as to the Mon-Khmer cultural substratum which underlay some Southeast Asian phenomenon. Linguistic similarities between the Mon-Khmer elements in Acehnese and Nicobar languages remain heavily controversial but needing further study. Nicobar's bilateral kinship system, tending to gender balance, matrilocality, and pairing monogamy with relatively easy divorce, suggests that Southeast Asia's unusually balanced gender system owed as much to the Mon-Khmer substratum as to the dominant Austronesian migration into the islands. Just as in parts of Indonesia, European visitors to Nicobar were astonished at female-initiated marriage and divorce, so that "a woman who has divorced or deserted more husbands is considered a proud lady” (Mathur 1968, 241-242, also 226; cf. Reid 1988, 152-158).

Early modern Nicobar also had a distinct partiality for female rulers, like Aceh and the Maldives before 1700 (Reid 2003, 31-35). In a generally stateless, kinship-oriented society, the earliest evidence we have of someone of raja-like status is in fact a Portuguese 'stranger queen', very rare in the region or anywhere. The Siam-based French bishop reported to his superiors in 1686, on the basis of the reports of recent visits to the islands, that the Nicobarese "have, among them, on the principal island, a Portuguese woman aged more than 80 , who having been wrecked on the island perhaps over 30 years ago, has been ever since treated by the people with extreme veneration and submissiveness." (Launay 1920, 87). This remarkable lady was, therefore, a contemporary of her neighbour in Aceh, Queen Taj al-Alam Safiyat al-Din Syah (1641-1675). The tradition of female rajas, or chieftains, remained strong through the twentieth century, though the influence of Indian administrations led to these dominant women becoming known as Rani (Whitehead 1924, 27). In particular Rani Ishlon of Nancowrie (1865-1954) became the most prominent indigenous leader in the Nicobars, and "united several islands under her dynamic leadership". She passed the mantle to her daughter, Rani Lachmi, who in turn passed it to her daughter (The Andaman Express, June 2, 2004).

\section{Pre-Islamic Commercial \& Cultural Connections}

Relics of Buddhist and Hindu influence, are not only absent from the western offshore islands of Sumatra, but also relatively scarce in its northern quarter where the Aceh sultanate later arose. Yet we can be sure that this relative scarcity of relics in comparison with Central and southern Sumatra does not indicate a lack of contact with India. On the contrary, Sumatra's northern coast must have been the first landfall of shipping across the Bay of Bengal, and the hub of India-Indonesia exchanges from the first common millennium. Some important pre-Islamic settlements on the west coast must have been destroyed by earthquakes and tsunamis, as seems likely to have been the case with the great camphor port known as Fansur (McKinnon 140).

The centrality of a mythic first polity of Lingga, and many other vestiges of Indian terms, concepts and practices (including chess), among the related Gayo, Pak-Pak and Karo peoples, demonstrate the importance of connections with India long before the rise of Aceh (Bowen 1991, 
215-30). The Karo marga of Sembiring [Si-Mbiring = the dark one] appears to have originated from an Indian colony on the coast. Its members until the twentieth century practised cremation, and used Indic terms, including Colia, Meliala, Malayalam, Berahmana and Keling, for its sub-marga (Rae 1994, 8-9; Kipp 1993, 15-16).

The Banda Aceh area, where the Aceh sultanate arose, was too strategically important to be abandoned as sites like Padang Lawas in Sumatra or Borobudur in Java were. The Hindu-Buddhist stone structures erected in this area were undoubtedly demolished or incorporated into new Islamic buildings. Aceh sultanate defined itself from its sixteenth century beginnings as a spearhead of Islam against both Portuguese and idol-worshippers. The most striking surviving example is the mosque of Indrapuri, but there was also an important Tamil inscription, similar to the commercial regulations sometimes incorporated into Hindu or Buddhist temples, found incorporated into a mosque ablution area in Banda Aceh (McKinnon 2006, 25-26). It is likely that there were other such Hindu-Buddhist stone structures also at the coastal sites remembered as Indrapatra and Indrapurwa, forming a triangle of remembered toponyms unusually Indic in character (Arif 2008).

These two coastal sites, which archaeologists have sought to link with Lamri and Fansur respectively, were undoubtedly affected by Aceh's geologically unstable coastline. Some structures associated with Indrapurwa are still visible beneath the water, while the EOS team in Singapore is confident that a vibrant commercial community associated with historic Lamri and mythic Indrapatra was wiped out by tsunamis between 1344 and 1394 (Sieh et al. 2015)

Although Sumatrans are inclined to defer to Java as the centre of Indian influence in the Archipelago, that status may in reality belong to northern Sumatra. New research on the Tamil merchant guild of the Ayyavole has made clear that it was northern Sumatra and the Peninsula portages that loomed large in its trading routes to China. This guild left at least four inscriptions in the area, and many more in India. One of them was the well-known stone pillar of Barus, taken to the Jakarta Museum during the Aceh-Dutch war, and in 1993 rediscovered there and re-translated by a group of Tamil scholars. Dated to 1088, this important monument implies a substantial Tamil merchant community in the port at that time (Subbarayalu 1998, 25-34; Karashima 2009, 56-57).

While the Tamil merchants were Hindu, a stronger imprint appears to have been left on Sumatra as a whole by Mahayana Buddhism, as practised in Sriwijaya and its many Sumatran successors. After the eleventh century peak of Tamil Hindu influence, the Buddhist links were continued between Sumatra and Bengal, then under the Buddhist Pala Dynasty (750-1154). Tomé Pires' Pasai informants believed that Pasai adopted Islam soon after Bengal did in the fourteenth century because of the very close relationship between the two kingdoms (Pires 1944, 143). Ibn Battuta was one of many who travelled from Bengal to Pasai in the 1340s, as a well-established route. There is no shortage of Sumatran references to all three regions of India that we today call Kerala, Tamilnadu and Bengal.

\section{Coming of Islam}

Given the dominance of shipping from Tamilnadu, Gujarat, and Kerala in the trade of Pasai and later Aceh from the earliest descriptions, it is no surprise that Indian references dominate the stories of northern Sumatra's Islamization.

According to the oldest of Malay texts, Hikayat Raja-Raja Pasai, probably first composed to inform one of the courts of Java about Pasai, Islam arrived from the already Muslim port-state of Mengiri or Miar, taken by the editors of its text to refer to Ma'abri, an originally Arab usage for describing the Tamil or Coromandel Coast of South India. The story begins with a pious reference to the Prophet in Mecca, who instructs his followers that when they hear that a negeri (polity) has arisen below the winds, they should send a ship there, calling first at Ma'abri, where they would find a fakir (holy man). They must take him to Semudra to carry out the conversion of the place. Ma'abri's ruler, Sultan Muhammad, decides when he hears this to go himself with the ship to Samudra, abandoning his throne to don the garments and lifestyle of a fakir. The conversion of Merah Silu to become the first Muslim Sultan Malikus-Saleh was of course accompanied by miraculous revelations. Then the ship departed, "but the [Tamil] fakir remained behind to establish (menetapkan) the religion of Islam firmly in negeri Samudra". The tribe $[\mathrm{kaum}]$ who would not embrace Islam "fled to 
the upper reaches [hulu] of the Peusangan River" and became known as Gayo (Alfian 1973, 48-53; Hill 1961, 116-20). To provide a date for this story Marco Polo in 1292 is useful. He described the people of Basman or Peusangan as still constituting a pre-Muslim kingdom claiming a tributary status with the Mongol Emperor of China, whose ship Polo was travelling on, but who were "without a law, except such as prevails among brute beasts."

The next story concerns another South Indian, probably Tamil 'Kling', who came on a trading ship from 'benua Kalinga' (Alfian renders it as simply Kling) to Samudra and found a local source of gold there which made the infant Islamic state rich (Alfian 1973, 57; Hill 1961, 123). Kalinga continues to be important in every new development the text chronicles in the successor kingdom known as Pasai. A yogi came from Kalinga to show his magic arts to the Sultan, but the latter's sanctity was such that he worsted the yogi, who thus became a Muslim. However, he (strangely) gave the Sultan the distinctly South Indian name of Perumudal Perumal (Alfian 1973, 71; Hill 1961, 134135). Perumal is a form of Vishnu venerated especially in Tamil areas. Knowing that this Sultan Ahmad carried a Tamil and basically Hindu name, the chronicler may have devised this story rather than acknowledge a South Indian origin of one of the sultans.

It appears probable that Indians began the systematic exploitation and export of the gold of Sumatra. Again, the Hikayat Raja-Raja Pasai as well as local Karo-Batak myth and a tenth-century Sanskrit inscription on a gold ring in Barus all point in this direction (Perret \& Surachman 2011, 166). In most of Southeast Asia it was the Chinese thirst for minerals, especially silver and tin but also gold, that brought advanced mining technology and capital into the region, but gold was a particular obsession of India. Its traders and miners since the first common millennium sourced the precious metal in what their scriptures called Suvarnadvipa [the gold island], most plausibly referring to Sumatra.

\section{Indian Shipping and the Rise of the Aceh Sultanate}

Before the 1510s, when the disruptions of the Portuguese gave rise to Aceh as a strongly Islamic and anti-Portuguese bastion, the trade of Pasai and other northern Sumatran port-states was overwhelmingly in the Bay of Bengal. "The merchants who trade in Pasai are Gujaratis, Klings, Bengalis, men of Pegu, Siamese, men of Kedah and Bruas". Traders did not come there from the Indonesian archipelago since all such vessels stopped in Melaka (Pires 1944, 144). Gujaratis, who regularly sent the six biggest cloth-laden ships to Melaka before it fell to the Portuguese in 1511, were the first victims and most determined opponents of Portuguese aggression in the region. By shifting their trade to Aceh as a sternly Islamic new power that would defy the Portuguese, they and other South Indian Muslim traders ensured the sultanate's prosperity (Reid 1993, 27). Aceh's alliance with the Muslim powers of Gujarat and South India formed part of a broader Turkish-inspired struggle against the Iberians in the Indian Ocean throughout the sixteenth century (Reid 2014; Farooqi 1989, 157-158).

Dutch and English reporting from 1600 provides more data about these intense commercial links, as Aceh acted as the principal port at the eastern end of Islamic trading routes in the Indian Ocean. Lancaster reported 16-18 Indian ships in the harbour of Banda Aceh in 1602. About half of these may have been the large Gujarati ships, carrying valued Gujarati cloth to exchange for the pepper and spices they took to Surat, and then on to the Persian Gulf for the Mediterranean. The Gujaratis were the first to have been hurt by the growing strength of Dutch and English shipping around Africa, and by mid-century only one or two continued to reach Aceh each year. Bengal and Tamil shipping were less affected, and continued to grow to mid-century, but tail off markedly from the 1680s (Reid 1993: 28-29; Subrahmanyam 1990, 151-153, 213-216). Nevertheless, the resident North Indian population was substantial in the port-capital in the 1680s. Dampier noted that most of the resident merchants and goldsmiths were Indian, and that every foreign trader needed a Gujarati agent to prevent being tricked in the handling of the many forms of current money (Dampier 1699/1931, 9096).

From the 1680s the long-distance trade carrying Southeast Asian pepper and spices to Europe can be said to have been wholly taken over by European ships sailing around the south of Africa. Batavia was at its peak as the strongest base for such trade. Aceh remained important as a free port, 
not dominated by the Dutch or any other maritime power, but its shipping was chiefly to South India on the one hand, and Straits ports on the other. Aceh had lost control of most of its former pepper exports, and instead exported chiefly elephants and betelnut [pinang] to South India, as well as gold to all comers. In consequence the port remained prosperous, and was "seldom without 10 or 15 sail of ships of several nations," including diverse Europeans, Gujaratis and Chinese. Gujaratis were still the chief resident merchants, buying up the cloth these ships imported from India, often against Aceh gold.

The eighteenth century saw the rise of Tamil Muslims, known locally as Chulias, to the greatest influence in the commerce of Aceh. Some commanded their own ships in the India-Aceh trade, but probably more served as lascars (soldier/seamen) on ships owned or captained by Europeans. Eighteenth century sultans tended to have a fragile hold on power, and became increasingly reliant on the Chulias to enforce their authority over the coastline. Sultan Ala'ud-din Mahmud Shah (176088) was such a ruler, whose key military asset was a force of a thousand South Indian soldiers brought in by his Chulia shahbandar, Kassim.

English 'country traders' and their Chulia crews also provided a tempting source of power, especially when it came to trying to force the European-captained ships to pay a duty to the Sultan on their trade to ports he did not fully control. When one such trader, Desvoeux, tried play such a role on behalf of the English East India Company of which he was also an agent, it produced a sharp reaction from interior Acehnese ever-suspicious of entrenching feringgi [Frankish, European] power. This private British establishment initiative had to be withdrawn in late 1772 (Hing 1995, 32-55).

Mahmud's son and successor Muhammad Syah (1781-90), a cosmopolitan figure who according to Forrest had been to Mauritius as well as Mecca and spoke French and Portuguese, employed another Chulia Muslim, Poh Salleh, as his shahbandar (Lee 1995, 61-66; Forrest 1792, 512). The Chulias continued influential in commerce right through the nineteenth century, though having to compete with influential Arabs in the long reign of Ibrahim Mansur Shah (1840-1870). The last Indian shahbandar, in the 1860s and '70s, was not a Chulia but a clever Tamil convert to Islam, who had come to Aceh as a boy in a travelling performing troupe (Reid 1969, 83).

\section{The 'Indian' Character of Aceh's Population}

The inhabitants of Aceh are fundamentally Austronesian in their languages, their religious and customary practices (especially gender relations), and their material culture. Nevertheless, the constant trade with south India up until the nineteenth century appears to have added a distinct south Indian strain to the population, still visible in Acehnese appearance. As well as the constant influx of traders, religious teachers and adventurers of various kinds, there was a deliberate import of unfree agricultural labour in the second half of the seventeenth century.

The remarkable ethnographer and Islamist Snouck Hurgronje recorded in the 1880s that "There have been within the memory of man a large number of Klings (south Indians) in the highlands of Great Acheh (XXII Mukims) living entirely as Achehnese and engaged in agriculture." (Hurgronje 1906, 19). Needless to say, they subsequently assimilated beyond any recollection of difference. The XXII Mukims (Islamic parishes) refers to the upper half of the Aceh river valley, above Banda Aceh, representing in modern times one of the major rice bowls of the Province. Snouck appears to be pointing here to a migration that began, even if it was not limited to, the seventeenth century.

The valley of the Aceh River, known as Aceh Besar, was little populated or cultivated except for the great metropolis of the capital until the late seventeenth century. Foreign observers noted the dependence of the capital on rice imports from Pidië, or even from the Peninsula and South India, even though there was land suitable for rice cultivation being put to little use (Ito 1984, 393-396; Lombard 1967, 61). Dampier, in 1688, had the same impression, but added that:

of late they have sown pretty large Fields of Rice. This thrives here well enough; but they are so proud, that it is against their Stomach to work: neither do they themselves much trouble their heads about it, but leave it to be managed by their Slaves: and they were the Slaves brought lately by the English and the Danes from the Coast of Coromandel, in the Time of a Famine there, I spoke of before, who first brought this Sort of Husbandry into such Request among the Achinese (Dampier, 1699/1931, 91). 
This large-scale movement of Indian slaves into agriculture in Aceh Besar was confirmed by another visitor, Charles Lockyer, a few decades later.

There are many Indians of the Coromandel coast.. Slaves to the great men and Merchants. To these the Acheenese owe the greatest part of their husbandry in managing their crops of Paddy, or Rice, which was hardly known on this part of the Island, till these were driven here by the famine from Fort St. David, and other places on the Coromandel Coast (Lockyer 1711, 54).

The population of this 22 Mukims area expanded rapidly in the eighteenth century, as that of the port and capital declined. Rice was no longer among the important imports of Aceh Besar in the eighteenth century, though it was not until the late colonial period that Aceh as a whole became a rice surplus area. In the twentieth century censuses (1930, and decennially from 1970) and ethnographies Aceh emerges as an agricultural society very different from the cosmopolitan, multiracial and commercially oriented place of the sixteenth and seventeenth century. There was little trace remaining of a distinct Indian population group.

According to the Italian adventurer Cesar Moreno, the last major influx from India of a significant military force was a group of Muslim participants in what the British called 'the Indian Mutiny', and Indian nationalists 'the Great Rebellion'. Many of its leaders, he said, fled India when the rebellion had failed in 1859, "and went as political refugees to Acheen, which was regarded as a kind of political Mecca." As a sympathizer with the rebels, Moreno came with them, and hence was well received in Aceh (Moreno 1873, 5).

Although as foreign power-brokers, South Indians had increasingly to compete with Arabs in the nineteenth century, the Indian connection remained strong up to the Dutch invasion of 1973. At least two India-born Aceh leaders played major roles in the diplomatic exchanges of the time, though both were seen as traitors once war broke out. Panglima Muhammad Tibang was the last shahbandar of the sultanate, in 1868-73, trusted by both Sultan Ibrahim and his young successor Mahmud (18701874) to deal with the powerful Europeans. He was not a Chulia Muslim like most of the influential Indians, but a clever Hindu boy who had deserted in Aceh from a touring performing troupe, and there converted and integrated in Aceh. He was twice sent off to represent Aceh in 1872-1873, to appeal for British or American protection in Singapore, while holding off the Dutch through Resident Schiff in Riau. He achieved the remarkable feat of interesting the U.S. Consul in Singapore, Major Studer, in an Aceh-US Treaty of alliance that would have stymied the Dutch. I may have given too negative a picture of him in my thesis, because he was the great rival of the Acehnese hero of my story, Abdur'rahman az-Zahir (Reid 1969, 83, 88-92). Finally, the India-born ulëëbalang of Idi, Teungku Chik, envied the wealth that had come to the Malay sultans of Deli and Langkat under Dutch auspices, and appealed for Dutch protection against Aceh and local rival Simpang Ulim (Reid 1969, $80,88)$.

\section{British India, Dutch Sumatra, and the Breaking of the Links}

Up until the mid-nineteenth century, Aceh remained the principal trading base for South India-based ships in the Straits region. About 12 such ships a year brought opium and cloth to Aceh, in exchange for the pepper of the west coast of the north coast (Reid 1969, 6).

The relationship with the Nicobar Islands was a natural neighbourly one, though the underdevelopment of that archipelago meant trade was very small-scale. Aceh traders in small vessels brought "cloth, knives and tobacco, which are the commodities most wanting in the Nicobars," in exchange for the coconuts and ambergris of the islanders, and occasionally slaves (Hamilton 1727/1930, 36). William Dampier in 1688 was one famous English trader who described his crossing from island to island from Great Nicobar until arriving at Pulau Wei. He had found the captain with whom he was sailing outrageously tyrannical, and used Nicobar as an escape, the Captain believing he would perish there among the generally hostile islanders. Instead, with the help of four Acehnese whom Captain Read had unjustly seized near Aceh and also abandoned in Nicobar, Dampier and his party managed to navigate back to Aceh and the relative safety of an English East India Company base there (Dampier 1699/1931, 80-90). 
Alexander Hamilton (1727/1930, 36-37) in 1694 encountered an Andaman Islander in Banda Aceh, who was making a living bringing mercury (quicksilver) from his homeland to market in Aceh. This man had been captured as a boy by Nicobarese in one of their frequent wars, and three years later sold by them as a trade item in Banda Aceh. After his master died he gained his freedom, and used it to navigate back to the Andamans in a small boat. He told Hamilton's informant that "the southernmost of the Nicobars may be seen" from Pulau Weh, so that he could navigate by sight from island to island.

Britain's need for a more easterly base to assist it's growing China trade proved crucial in realigning commerce in the area. They examined Aceh, the Andamans and Nicobars and Phuket for this purpose, but settled on Penang in 1786. Gradually that port became more important as a staple port than Aceh, usurping the latter decisively in mid-century as steamers made it a stapling port on their long-distance routes. The many hostile Indian captives they made as a result of the 1857 'Indian Mutiny' convinced the British Indian government that they must establish an Indian penal colony in a remote place like the Andamans.

So little did British India know about the famously ferocious islanders at the time that in 1859 they sent the first British Superintendent of the new settlement, Captain Haughton, first to Penang and Aceh to learn about them. He hoped to find some Andamanese slaves grown civilized in Aceh, who could help as interpreters. We will never know how many such slaves there might have been, since Sultan Ibrahim so sympathised with the Indian rebels to whom he had given refuge that he refused to meet Haughton and sent him packing the next day (Portman 1899, 291-292; Reid 1969, $85)$.

The British colonies at the Andaman and subsequently (1869) Nicobar Islands continued to be very difficult to govern, but this intervention nevertheless proved the definitive moment of tying the islands to distant India rather than to their neighbours in Sumatra or the Peninsula. Penang and Rangoon remained the chief markets and supply points for the new colony, increasingly in the hands of Penang Chinese traders later denounced by British Indian authorities for having given them "drinks and petty articles in place of copra" (Mathur 1968, 303). Kloos $(1903,154)$ recorded that the last "Malay" (presumably including Acehnese) vessel to trade in Nicobar coconuts arrived in 1877 . The new migrant population of both Andamans and Nicobars, however, became overwhelmingly Indian - whether convict or free.

Any chance that Aceh's fate would be separate from that of the rest of Indonesia was ended in the Anglo-Dutch Treaty of 1871, when Britain traded away its 'guarantee' of Aceh independence earlier agreed in the 1824 Anglo-Dutch Treaty. Having declared war on Aceh in 1873, the Netherlands used its fleet to prevent all foreign trade with Aceh except its lifeline with British Penang. That port was too important for supplying the Dutch, and its traders for lobbying London against the attempted Dutch blockades, to allow the lifeline to be cut. Up until the war the Chulias had still been taking about 60,000 pikuls (3,600 metric tons) of betelnut to India from 'the Pedir coast' (North Aceh) every year. That stopped abruptly in 1873, and the traders were obliged to try to continue to get the betelnut out through Penang. Even that indirect avenue was severely curbed in the harsher trade regulations introduced in the 1890s (Reid 1969, 116 and passim).

\section{The Fate of Peripheries in a Nationalist World}

When peace returned to Aceh after 1912, some efforts were made to revive the betelnut trade to India, though it amounted to little more than a trickle. The independence of India and Indonesia in no way helped restore the connection. Neither Nehru's India nor Sukarno's Indonesia favoured open trade borders, and the relations between the two were frequently frosty following the Bandung Conference (1955). India placed the Andamans and Nicobars under the military administration of the Navy, and closed their border completely for any trade or communication not only with Indonesia, but with the formerly British territories of Burma and Malaya which had been its principal suppliers. The Indian Government established a monopoly of purchasing Nicobar coconuts (Mathur 1968, 303).

Both powers appeared to regard their respective frontier areas as troublesome peripheries to be denied normal contacts with their neighbours. Indonesia's paranoia about Aceh seemed justified after 
the rebellion in 1953. Like Batavia, Jakarta again attempted to use control of trade as a means to enforce compliance, though initially with less naval hardware to impose its blockades. The barter trade with the Peninsula was briefly encouraged by Governor Syammaun Gaharu in 1958, but closed again when Sabang operated as a free port in 1960-1985. Thereafter, "all Aceh's produce during the New Order except natural gas and fertiliser was exported through Belawan” (Sulaiman 2006, 134).

India's paranoia about its island frontier is harder to explain, since there is no overt evidence of rebellion or subversion in the Islands. They are of course seen as a strategic asset in India's ambitions in the Indian Ocean. Yet as an asset in India's proclaimed policy of improved relations with Southeast Asia, they are surely equally valuable. Like other 'troublesome peripheries' in a nationalist world, Aceh/North Sumatra and Andaman/Nicobar have much to gain in a new era of increasingly open frontiers and global consciousness.

\section{References}

Alfian, T. Ibrahim. 1973. Kronika Pasai: Sebuah Tinjauan Sejarah. Jogjakarta: Gadjah Mada University Press.

Arif, Kamal. 2008. Ragam Citra Kota Banda Aceh: Interpretasi Sejarah, Memori Kolektif dan Arketipe Arsitekturnya. Banda Aceh: Pustaka Bustanussalatin.

Bowen, John. 1991. Sumatran Politics and Poetics: Gayo History, 1900-1989. New Haven: Yale University Press.

Dampier, William. 1699/1931. Voyages and Discoveries, Wilkinson, C. ed. London: Argonaut Press.

Farooqi, Naimur R. 1989. Mughal-Ottoman Relations: A Study of Political and Diplomatic Relations between Mughal India and the Ottoman Empire, 1556-1748. Delhi: Idarah-i Adabiyat-i Delhi.

Forrest, T. 1792. A Voyage from Calcutta to the Mergui Archipelago. London: J. Robson.

Hamilton, Alexander. 1930. A New Account of the East Indies [1727], edited by William Foster. London: The Argonaut Press.

Hill, A.H., ed. 1931. "Hikayat Raja-Raja Pasai", romanised and translated by A.H.Hill. Journal of the Malayan Branch, Royal Asiatic Society 33 (2).

Hing, Lee Kam. 1955. The Sultanate of Aceh: Relations with the British, 1760-1824. Kuala Lumpur: Oxford University Press.

Karashima, N. 2009. "Medieval Commercial Activities in the Indian Ocean as Revealed from Chinese Ceramic-sherds and South Indian and Sri Lankan Inscriptions." In Nagapattinam to Suvarnadwipa: Reflections on the Chola naval expeditions to Southeast Asia, edited by Hermann Kulke, K. Kesavapany and Vijay Sekhuja, 20-60. Singapore: Institute of Southeast Asian Studies.

Kipp, R. 1993. Dissociated Identities: Ethnicity, Religion and Class in an Indonesian Society. Ann Arbor: University of Michigan Press.

Kloos, C. Boden. 1903. In the Andamans and Nicobars: The Narrative of a Cruise in the Schooner "Terrapin," with Notices of the Islands, Their Fauna, ethnology, etc. London: John Murray.

Launay, Adrien. 1920. Histoire de la Mission de Siam, 1662-1811, Documents Historiques. Paris: P. Téqui.

Lockyer, Charles. 1711. An Account of the Trade in India. London: S. Crouch.

Lombard, Denys. 1967. Le Sultanat d'Atjèh au temps d'Iskandar Muda 1607-1636. Paris: Ecole Française d'Extrême-Orient.

Mathur, L. P. 1968. History of the Andaman and Nicobar Islands (1756-1966). Delhi-6: Sterling Publishers.

McKinnon, E. Edwards. 2011. "Continuity and Change in South Indian Involvement in Northern Sumatra: The Inferences of Archaeological Evidence from Kota Cina and Lamreh.” In Early Interactions Between South and Southeast Asia: Reflections on Cross-Cultural Exchange, edited by P-Y Manguin, A.Mani, Geoff Wade, 137-60. Singapore: ISEAS, 2011.

McKinnon, E. Edwards. 2006. "Indian and Indonesian Elements in Early North Sumatra." In Verandah of Violence: The Background to the Aceh Problem, edited by Anthony Reid, 2237. Singapore: Singapore University Press. 
Moreno, Celso C. 1873. "Acheen. The Sultan's Minister Sketches the Country." New York Herald, May 16 1873, p.5.

Perret, Daniel and Heddy Surachman 2011. "South Asia and the Tapanuli Area (North-West Sumatra): Ninth-Fourteenth Centuries." In Early Interactions Between South and Southeast Asia: Reflections on Cross-Cultural Exchange, edited by P-Y Manguin, A.Mani, Geoff Wade, 161-75. Singapore: ISEAS.

Pires, Tomé. 1944. The Suma Oriental of Tomé Pires, ed. A. Cortesão. Cambridge: Hakluyt.

Portman, M. V 1899. A History of our Relations with the Andamanese. Calcutta, Government Printer.

Rae, S. 1994. Breath Becomes the Wind: Old and New in Karo Religion. Dunedin: University of Otago Press.

Reid, Anthony. 1969. The Contest for North Sumatra: Atjeh, the Netherlands and Britain, 18581898. Kuala Lumpur: Oxford University Press/University of Malaya Press.

Reid, Anthony. 1988. Southeast Asia in the Age of Commerce, Vol. I: The Lands Below the Winds New Haven: Yale University Press,.

Reid, Anthony. 1993. Southeast Asia in the Age of Commerce, Vol. II: Expansion and Crisis. New Haven: Yale University Press.

Reid, Anthony. 2005. An Indonesian Frontier: Acehnese and other Histories of Sumatra. Singapore: Singapore University Press.

Reid, Anthony. 2014. "Turkey as Aceh's Alternative Imperium.” Archipel 87: 81-102.

Sieh, K., Patrick Daly, E.E. McKinnon et al. 2015. "Penultimate Predecessors of the 2004 Indian Ocean Tsunami in Aceh, Sumatra: Stratigraphic, Archeological, and Historical Evidence," JGR Solid Earth 120 (1): 308-325. doi:10.1002/2014JB011538.

Snouck Hurgronje. 1906. The Achehnese, trans A.W.S. O'Sullivan. Leiden: Brill.

Subrahmanyam, Sanjay. 1990. The Political Economy of Commerce: Southern India, 1500-1650, Cambridge: Cambridge University Press.

Sulaiman, M. Isa. 2006. "From Autonomy to Periphery: A Critical Evaluation of the Acehnese Nationalist Movement." In Verandah of Violence: The Background to the Aceh Problem, edited by Anthony Reid, 121-48. Singapore University Press/University of Washington Press, 2006.

Takeshi, Ito. 1984. "The World of the Adat Aceh: A Historical Study of the Sultanate of Aceh." Ph.D. Dissertation, Australian National University.

The Andaman Express. June 2, 2004.

Whitehead, George. 1924. In the Nicobar Islands. London: Seeley, Service \& Co.s. 